\title{
Effect of dietary concentration of crude protein and Synovex-C on skeletal growth of dairy heifers
}

\author{
A. Shamay, I. Bruckental, U. Moallem and Hanina Barash ${ }^{*}$
}

\author{
Institute of Animal Science, Agricultural Research Organization, \\ The Volcani Center \\ Bet Dagan 50250. Israel
}

(Received 25 May 1999; accepted 7 October 1999)

\begin{abstract}
Eighteen prepubertal Israeli-Holstein heifers were used in an experiment to study the effects of protein supplementation and implantation of Synovex-C on body weight gain (BWG), skeletal size and age at puberty. Heifers were allocated to three treatment groups as follows: 1. heifers received a diet that was formulated according to NRC (1989; Control) recommendations. 2. heifers received the same diet fed to heifers on treatment 1 except that the dict was supplemented with $3.3 \%$ maize gluten meal (MGM) during the first 6 months and with $2.5 \%$ MGM during the next 3 months 3 . heifers received the same diet fed to heifers on treatment 2 and were implanted with Synovex-C. Supplementation of MGM to the diet enhanced BWG during the first $183 \mathrm{~d}$ of the experiment. The implantation of Synovex-C enhanced BWG only during the first $92 \mathrm{~d}$ of the experiment. From $\mathrm{d} 93$ to 281 , BWG of heifers on treatment 3 was reduced, and, by the end of the experiment, the BW of these heilers tended to be lower than of heifers on treatment 2. Supplementation of MGM to the diet enhanced growth rates of the wither and hip during the first 281 of the experiment. However, inplantation of Synovex-C eliminated the effect of supplemented MGM, and, towards the end of the experiment, withers and hip heights of heifers on treatment 3 were lower than those of heifers on treatment 1. Implantation of Synovex-C was associated with increased serum JGF-1 during the first $150 \mathrm{~d}$ of the experiment and with reduced age and wither height at puberty.
\end{abstract}

KEY WORDS: heifers, undegradable protein, Synovex-C, skeletal growth

\section{INTRODUCTION}

Replacement heifers contribute to a large proportion of the total cost of milk production (Heinrichs, 1993), and delay of first calving has an impact on total

\footnotetext{
- Corresponding author
} 
costs. However, calving at an early age may result in reduced milk production during the first lactation and increased incidence of dystocia (Foldager and Sejrsen, 1991; Sejrsen 1994; Hoffman, 1997). Body weight (BW) at first calving was found to be positively correlated with primiparous milk production (Hoffman, 1997). Although BW and wither height (WH) are closely correlated (Heinrichs and Hargrove, 1987; Heinrichs et al., 1992), the correlation between WH and primiparous milk production was higher than that observed between yield and BW (Heinrichs and Hargrove, 1987; Heinrichs et al., 1992; Markusfeld and Ezra, 1993). Compensatory growth of heifers was found to be limited (Ryan, 1990; Barash et al., 1994 a,b; Radcliff, 1997). Implantation of Synovex-C in 3-months-old beef heifers significantly enlarged their pelvic area before calving and tended to reduce calving difficulties (Deutscher et al., 1991; Rusk et al., 1992). An increase in CP concentration by $2 \%$ between the ages of 3 and 12 months resulted in an increased BW and WH of heifers (Amos, 1986; Kertz et al., 1987). Rates of BW gain (BWG) and nitrogen retention in steers treated with estrogenic growth promoters were enhanced as metabolisable energy (ME) and crude protein (CP) intake increased (Rumsey and Hammond, 1990).

The goal of the present experiment was to study the effect of an increase in dietary CP by $2 \%$ above NRC (1989) recommendations and of the implantation of Synovex-C, during the prepubertal period on BWG and skeletal size of IsraeliHolstein heifers.

\section{MATERIAL AND METHODS}

\section{Heifers and treatments}

Eighteen Israeli-Holstein heifers ( $87 \pm 4 \mathrm{~d}$ of age; $109.7 \pm 4.1 \mathrm{~kg}$ of BW) were allocated to three treatment groups according to their BW, age, and WH. The treatments were as follows: 1. the heifers were fed a diet formulated according to NRC (1989; Table 1) (Control), 2. the heifers were fed the same diet as treatment 1 , supplemented with $3.3 \%$ maize gluten meal (MGM; $60 \% \mathrm{CP}$ ) for the first 6 months to increase the CP concentration by $2 \%$ and, with $2.5 \%$ MGM for the next 3 months to increase CP concentration by $1.5 \%$. 3. The heifers were fed the same diet as treatment 2, and were implanted with a slow-release preparation of Synovex-C (100 mg of progesterone plus $10 \mathrm{mg}$ of estradiol benzoate; Syntex, Palo Alto, CA). Implantation was carried out according to the manufacturer instructions in the right ear.

Heifers were housed in the shade, each group in a separate pen. After $8 \mathrm{~d}$ of adaptation, the experimental diets were offered, and Synovex-C pellets were implanted. Diets were given collectively to experimental groups and the heifers had 
TABLE 1

Ingredients and chemical composition of control diet', g/kg

\begin{tabular}{|c|c|c|c|c|c|}
\hline \multirow[b]{2}{*}{ Ingredients } & \multirow[b]{2}{*}{3 to 6} & \multirow[b]{2}{*}{6 to 9} & \multicolumn{2}{|c|}{ Age, months } & \multirow[b]{2}{*}{16 to 22} \\
\hline & & & 0 tol2 & 13 to 15 & \\
\hline Barley grain, cracked & 28 & - & - & - & 280 \\
\hline Sorghum grain & 50 & - & - & + & - \\
\hline Maize grain, cracked & 158 & - & - & - & - \\
\hline Whole cottonseed & 105 & & - & - & - \\
\hline Wheat bran & - & - & - & - & 87 \\
\hline Soyabean meal & 74 & 88 & 40 & - & 155 \\
\hline Cottonseed mea! & 24 & - & - & - & - \\
\hline Rapeseed meal & 24 & - & - & - & - \\
\hline Vetch hay & - & - & 250 & 527 & - \\
\hline Wheat straw & - & - & - & - & 190 \\
\hline Wheat hay & 34 & 190 & - & 184 & - \\
\hline Maize silage & 316 & 715 & 700 & 289 & - \\
\hline Pea silage & 20 & - & - & - & - \\
\hline Orange peels & 110 & - & - & - & 30 \\
\hline Cottonseed hulls & 21 & - & - & - & 240 \\
\hline Urea & 1.4 & - & - & - & 8 \\
\hline Dicalcium phosphate & 4 & 4 & 4 & 4 & 4 \\
\hline Ground limestone & 14 & - & - & - & - \\
\hline Salt, minerals and vitamins ${ }^{2}$ & 20 & 4 & 4 & 4 & 4 \\
\hline \multicolumn{6}{|l|}{ Chemical composition } \\
\hline crude protein & 160 & 119 & 117 & 118 & 119 \\
\hline acid detergent fibre & 194 & 264 & 264 & 328 & 315 \\
\hline neutral detergent fibre & 315 & 481 & 449 & 499 & 478 \\
\hline $\mathrm{ME}^{3}, \mathrm{Mcal} / \mathrm{kg}$ & 2.83 & 2.5 & 2.36 & 2.26 & 2.26 \\
\hline
\end{tabular}

' diet formulated according to NRC (1989)

2 containing $16 \times 10^{6}$ IU of vitamin A, $3.2 \times 10^{6}$ IU of vitamin D, $16 \times 10^{6} \mathrm{IU}$ of vitamin E, $48 \mathrm{~g}$ of $\mathrm{Mo}, 48 \mathrm{~g}$ of $\mathrm{Zn}, 48 \mathrm{~g}$ of Fe, $19.2 \mathrm{~g}$ of $\mathrm{Cu}, 3.4 \mathrm{~g}$ of I, $0.32 \mathrm{~g}$ of $\mathrm{Co}$, and $0.48 \mathrm{~g}$ of Se ${ }^{3}$ metabolisable energy

free access to feed and water. Diets were offered every day at $08.30 \mathrm{~h}$ and residuals were collected every other day.

Heifers were weighed weekly during the first 9 months of the experiment and then every 2 weeks until calving. The WH, hip height $(\mathrm{HH})$, and body condition score of the heifers were determined once monthly.

Blood was withdrawn from the jugular vein using heparinized vacutainers and centrifuged at $2000 \mathrm{~g}$ for $10 \mathrm{~min}$, and the plasma was separated and stored at $-20^{\circ} \mathrm{C}$ until analysis. For progesterone determination, blood samples were collected weekly from 4 months of age until puberty. 
Blood for insulin, IGF-1, and total thyroxin analyses was sampled on d 30, 150, 280 and 430 of the experiment. The blood was taken at $08.40,09.00,09.20$ and $09.40 \mathrm{~h}$. The blood was left to coagulate at room temperature $\left(25^{\circ} \mathrm{C}\right)$ for $30 \mathrm{~min}$, cooled with ice, kept for $6 \mathrm{~h}$ at $5^{\circ} \mathrm{C}$, and subsequently centrifuged at $2000 \mathrm{~g}$ for $20 \mathrm{~min}$. The serum was separated and stored at $-20^{\circ} \mathrm{C}$ until analysis.

\section{Analyses}

The chemical composition of the diets was determined according to the AOAC (1970). Radioimmunoassays were employed for the determinations of hormones using commercial kits. Progesterone was determined using CoatA-Count ${ }^{(B)}$ (DPC, Los Angeles, CA, USA), insulin was determined using INSIK $-5^{\circledR}$ (Sorin Biomedica, Salluggia, Italy), total thyroxin was determined using Coat-A-Count ${ }^{(i)}$, and IGF-1 was determined using NR:53065 ${ }^{\circledR}$ (INCSTAR, Stillwater, MN).

\section{Statistical procedure}

Data for $\mathrm{BW}, \mathrm{WH}$ and $\mathrm{HH}$ were analyzed using the repeated measurement approach according to the GLM procedure of SAS (1988). Overall analyses of covariance of repeated measurements type were carried out with the measurement at $t_{0}$ as covariant. It was followed by separate analyses of covariance for each time. Differences among treatment means were tested by Student Neyman - Keuls (SNK) test. Data for the hormone concentrations in the serum and age, BW, and WH at puberty were analyzed using ANOVA (SAS, 1988). Statistical difference was determined at $\mathrm{P}<0.10$.

\section{RESULTS AND DISCUSSION}

\section{Body weight and skeleton measurements}

The BW, WH and $\mathrm{HH}$ of the heifers during the experimental period are presented in Table 2 and Figure 1. BWG of heifers on treatment 2 during the first 6 months of the experiment was greater than that of heifers on treatment 1 and their BW became $31.6 \mathrm{~kg}$ heavier than the BW of heifers on treatment $1(\mathrm{P}<0.01)$. This difference persisted until the end of the experiment 10.5 months later $(\mathrm{P}<0.07$; Figure 1a). The WHG of heifers on treatment 2 was greater than that of control heifers during the first 9 months of the experiment, and WH at d 281 was $2.9 \mathrm{~cm}$ more than of the control heifers $(\mathrm{P}<0.01$; Table 2$)$. This difference persisted until the end of the experiment 7.5 months later $(P<0.10$; Figure $1 b)$. The pattern 
of increase in $\mathrm{HH}$ for heifers on control and treatment 2 was similar to the increase in WH noted for these heifers during the whole experimental period, although significant differences were found only during the first 9 months of the experiment $(\mathrm{P}<0.02$; Table 2 and Figure $\mathrm{Ic})$. The positive response of $\mathrm{BWG}$ and WHG of heifers in the present experiment to an elevated CP concentration is in agreement with the findings of Bagg et al. (1985) and Kertz et al. (1987). Positive effects on heifers BWG and WHG were reported also for diets containing above $16 \%$ CP of which $50 \%$ was undegradable intake protein (Amos, 1986; Tomilinson et al., 1990, 1991; Casper et al., 1994).

TABLE 2

Body weight $(\mathrm{kg})$, and wither and hip heights (WH and $\mathrm{HH})(\mathrm{cm})$ of heifers during the experimental period

\begin{tabular}{|c|c|c|c|c|c|}
\hline \multirow[b]{2}{*}{ Days on experiment } & \multicolumn{3}{|c|}{ Treatment' } & \multirow[t]{2}{*}{ SEM } & \multirow[t]{2}{*}{$\mathrm{P}>\mathrm{F}$} \\
\hline & 1 & 2 & 3 & & \\
\hline \multicolumn{6}{|l|}{ Body weight, kg } \\
\hline initial & 111.0 & 111.2 & 110.3 & & \\
\hline 92 & $192.5^{b}$ & $202.8^{\mathrm{ab}}$ & $210.2^{3}$ & 13.4 & 0.08 \\
\hline 183 & $261.7^{b}$ & $293.3^{4}$ & $296.5^{i}$ & 15.7 & $<0.01$ \\
\hline 281 & 331.8 & 365.7 & 350.0 & 41.2 & $N S^{d}$ \\
\hline 393 & 409.2 & 439.3 & 429.3 & 28.3 & NS \\
\hline 503 & $482.8^{b}$ & $521.5^{a}$ & $504.7^{\mathrm{bb}}$ & 26.0 & 0.07 \\
\hline \multicolumn{6}{|l|}{ Wither height, $\mathrm{cm}$} \\
\hline initial & 88.6 & 88.5 & 89.0 & & \\
\hline 92 & 102.3 & 104.0 & 101.7 & 2.02 & NS \\
\hline 183 & $111.5^{\mathrm{b}}$ & $114.3^{\mathrm{a}}$ & $110.8^{\mathrm{b}}$ & 1.85 & 0.02 \\
\hline 281 & $118.4^{\mathrm{b}}$ & $121.3^{\mathrm{a}}$ & $116.6^{\circ}$ & 1.29 & $<0.01$ \\
\hline 393 & $123.5^{\mathrm{b}}$ & $126.4^{a}$ & $122.1^{\mathrm{b}}$ & 2.87 & 0.08 \\
\hline 503 & $128.5^{\mathrm{ab}}$ & $131.2^{2}$ & $126.7^{\mathrm{b}}$ & 3.18 & 0.10 \\
\hline \multicolumn{6}{|l|}{ Hip height, $\mathrm{cm}$} \\
\hline initial & 92.5 & 94.5 & 93.0 & & NS \\
\hline 92 & 107.6 & 109.3 & 106.6 & 1.47 & NS \\
\hline 183 & $117.3^{\mathrm{b}}$ & $120.7^{4}$ & $117.0^{\mathrm{b}}$ & 1.74 & 0.04 \\
\hline 281 & $122.0^{\mathrm{b}}$ & $127.8^{\mathrm{a}}$ & $123.3^{b}$ & 2.40 & 0.02 \\
\hline 393 & 128.1 & 131.2 & 128.9 & 2.85 & NS \\
\hline 503 & 132.6 & 135.3 & 131.8 & 3.26 & NS \\
\hline
\end{tabular}

a.h.s - means within a row without a common super script differ according to $P$ value given $d-P>0.1$

1 the heifers were fed a diet formulated according to NRC (1989). 2, The heifers were fed the same diet as treatment 1, supplemented with 3.3\% CGM for the first 6 months and, with $2.5 \%$ CGM for the next 3 months 3 . The heifers were fed the same dict as treatment 2 , and were implanted with a slow-release preparation of Synovex-C 

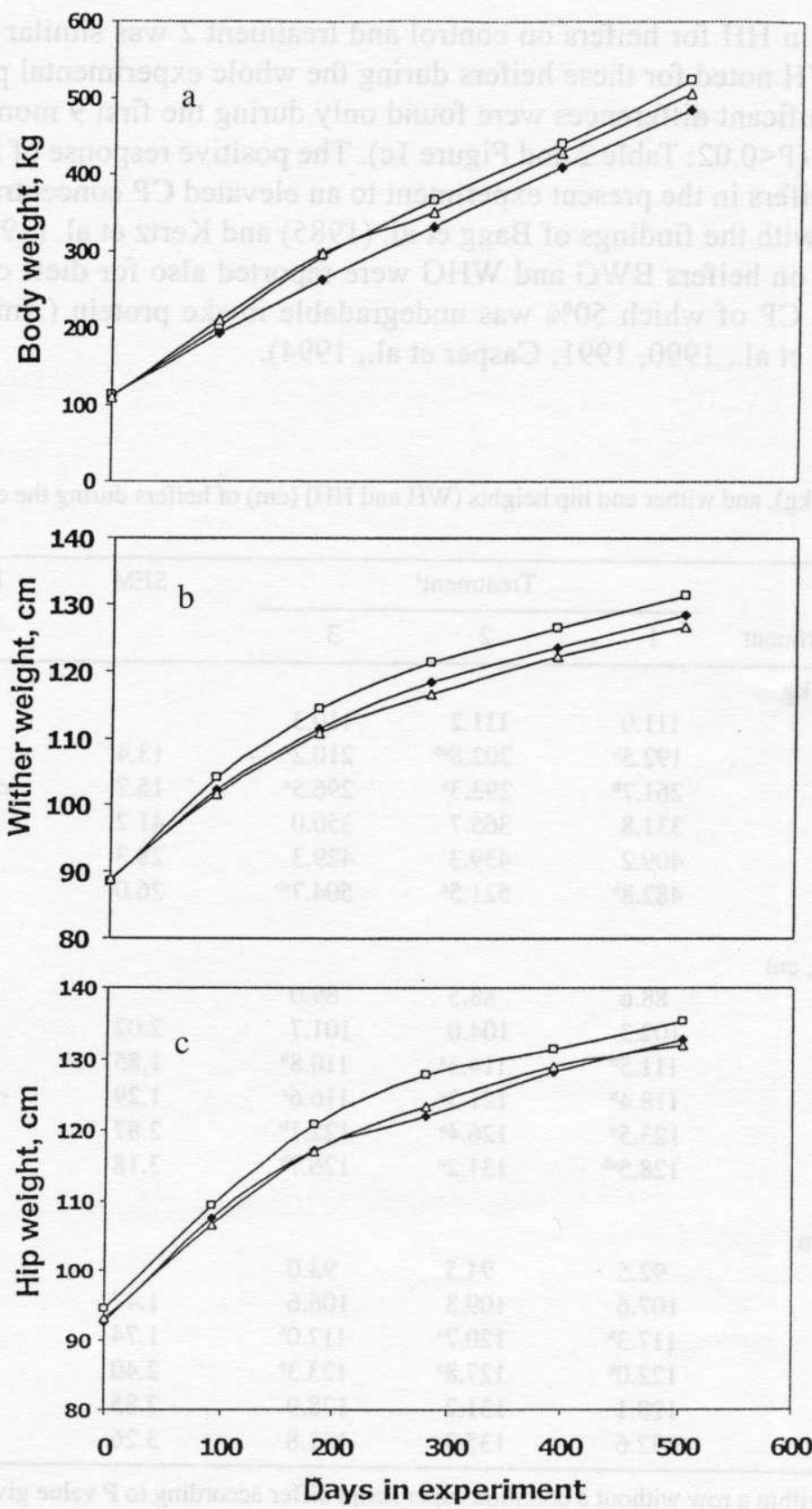

Figure 1. The effect on body weight (a), wither height (b) and hip height (c) of heifers fed a control $\operatorname{diet}(\bullet)$ or the control diet supplemented with protein $(\square)$ or heifers fed the control diet supplemented with protein and implanted with Synovex-C $(\Delta)$, during experimental period 
Heifers on treatment 3 had a different pattern of BWG, WHG, and $\mathrm{HH}$ gain (HHG) than did heifers on treatments 1 and 2 (Table 2 and Figure 1). During the first 3 months of the experiment they gained $99.9 \mathrm{~kg}$, whereas heifers on treatments 1 and 2 gained $81.5 \mathrm{~kg}$ and $91.6 \mathrm{~kg}$, respectively ( $\mathrm{P}<0.08$; Table 2 ). From this time until the end of the experiment, the BWG of heifers on treatment 3 slowed down in comparison with that of heifers on treatment 1 and 2, and heifers on treatments 1,2 , and 3 gained 221.2,228.2, and $208.2 \mathrm{~kg}$, respectively (Table 2 and Figure la). At the end of the experiment the BW of heifers on treatment 3 was lower than that of heifers on treatment $2(\mathrm{P}<0.1)$. The WH of heifers on treatment 3 was significantly lower than that of heifers on treatment 2 and tended to be lower even than that of control heifers (Table 2 and Figure 1b). During the 16.5 months of the experiment, WHG for heifers on treatment 1,2 , and 3 was $39.9,42.7$, and $37.7 \mathrm{~cm}$, respectively $(\mathrm{P}<0.10$; Table 2$)$. The pattern of $\mathrm{HHG}$ for heifers on treatment 3 was similar to their pattern of WHG. HH of heifers on treatment 3 were significantly lower than that of heifers on treatment 2 only on day 183 and 281 of the experiment (Table 2) but tended to be so during the whole experimental period (Figure 1c). Accordingly, at the end of the experiment, the HHG for heifers on treatment 1,2 , and 3 were $40.1,40.8$, and $38.8 \mathrm{~cm}$, respectively.

The positive effect of Synovex-C on the BWG of heifers during the first $92 \mathrm{~d}$ of the experiment is in agreement with previous findings (Roch and Quirke, 1986; Madar et al., 1992). The repression of BWG starting 92 to $183 \mathrm{~d}$ after the implantation of Synovex-C is consistent with results from our previous study in which the withdrawal of the growth promoter Cimaterol was followed by a repression in BWG (Barash et al., 1994b). The inhibitory effect of Synovex-C on the WHG and HHG observed in the present experiment is in agreement with the report of Russel et al. (1995), regarding a dose-dependent inhibition of estrogen implantation on longitudinal growth of ovariectomized rats and mice. The inhibitory effect is also consistent with additional studies (Russel et al., 1995) that have shown that estrogen administration during early postnatal and prepubertal periods resulted in the shortening of the limbs of rats. When Synovexc-C was implanted to Charolais and Salers steers and heifers, the length of the metacarpus of the implanted steers was shorter and that of the heifers was similar as compared with the control ones (Hardt et al., 1995).

It can be concluded that supplementation of growing heifer diet with undegradable protein above NRC (1989) recommendations, enhances their skeletal growth rate. Likewise, the pattern of BWG and skeletal growth of heifers treated with Synovexc-C is different than that of heifers on treatment 2 that were fed with supplemental CP only. This indicates that nutritional and hormonal treatments can affect differently BWG and skeletal growth, and the rate of BWG does not mean always a similar skeletal growth rate. 


\section{Feed intake and efficiency}

The efficiencies of dietary metabolisable energy (ME) and of CP for BWG are presented in Table 3. No statistical analysis was carried out because feed intake was determined for groups and not individually. During the first 6 months of the experiment additional $\mathrm{CP}$ and Synovex-C implantation tended to improve the efficiency of dietary ME utilisation for BWG. During the next 3 months of the experiment Synovex-C implantation tended to reduce the efficiency of dietary $\mathrm{ME}$ and of dietary CP utilisation for BWG, as compared to treatments 1 and 2. Positive effects of increased dietary protein concentration and degradability and of carbohydrate structure on feed efficiency for BWG of Holstein and Jersey heifers, have already been reported (Amos, 1986; Tomilinson et al., 1990, 1991). This combination of carbohydrates and proteins from a diversity of sources is probably an important factor of the effect of dietary protein on the growth of heifers as presented by Hoffman (1997). The high efficiency of dietary ME and CP conversion to BWG by heifers implanted with Synovex-C is in agreement with the results obtained for steers and heifers implanted with estrogenic growth promoters (Rumsey and Hammond, 1990; Rusk et al., 1992). Interestingly the synchronization between the transient severe retardation in BWG and the reduction in the efficiency of $\mathrm{ME}$ and of CP intake for BWG occurred between d 184 and 281 of the experiment. In a previous study, Barash et al. (1994b) reported on a transient severe retardation in BWG and feed efficiency for BWG after the $\beta$-agonist Cimaterol was withdrawn from the diets of growing heifers. The combination of retardation in BWG after Cimaterol withdrawal, without change in normal feed consumption was found to create a fattening situation (Hanrahan et al., 1988; Williams, 1988).

TABLE 3

Dry matter intake (DMI) and efficiency of metabolisable energy (ME) and crude protein (CP) intakes for body weight gain (BWG) during the experimental periods

\begin{tabular}{llccc}
\hline \multicolumn{4}{c}{ Treatment' } \\
\hline Days on experiment & & control & high CP & high CP + S \\
\hline 0 to 92 & DMI, kg/d & 4.7 & 4.7 & 4.8 \\
& ME intake/BWG & 15.0 & 13.3 & 12.5 \\
& CP intake/BWG & 0.85 & 0.85 & 0.79 \\
93 to 183 & DMI, kg/d & 5.7 & 5.9 & 6.1 \\
& ME intake/BWG & 18.8 & 14.8 & 15.8 \\
& CP intake/BWG & 0.89 & 0.82 & 0.88 \\
184 to 281 & DMI, kg/d & 6.5 & 6.5 & 6.5 \\
& ME intake/BWG & 21.4 & 20.8 & 28.1 \\
& CP intake/BWG & 1.06 & 1.23 & 1.67 \\
\hline
\end{tabular}

1 see footnote in Table 2 


\section{Puberty attainment}

Results of age, BW and WH at puberty attainment are presented in Table 4. Heifers on treatment 2 attained puberty $15.1 \mathrm{~d}$ earlier than did control heifers with no significant difference in WH (Table 4). Similar results were obtained by Radcliff et al. (1997), as high-CP, high-energy diet increased BWG and decreased age at puberty but had no effect on WH at puberty. The implantation of Synovex-C to heifers on treatment 3 induced earlier puberty by $38.1 \mathrm{~d}$ as compared with the control heifers $(\mathrm{P}<0.08)$, and their $\mathrm{WH}$ was shorter by $4.5 \mathrm{~cm}(\mathrm{P}<0.08)$. In previous studies it was shown that age and $\mathrm{BW}$ at puberty attainment could fluctuate and that the determinant factor for puberty initiation is probably the rate of fattening (Peri et al., 1993; Barash et al., 1994 a,b). The earlier puberty attainment of treatment 3 was probably a result, of a combination of retardation in BWG with normal feed consumption which induced a fattening situation (Hanrahan et al., 1988; Williams, 1988), enough for puberty initiation. Earlier attainment of puberty at the age of 3 months was reported also for Angus calves implanted with Synovex-C (Rusk et al., 1992). A retardation in the rate of gain of wither and hip heights after pubertal attainment is shown in Figure $1 b$ and $c$. It supports the idea that enhanced skeletal growth could be better induced before pubertal attainment.

Implantation of Synovex-C was accompanied by a transient enlargement of the udder. To quantify this effect, the distance between the right rear teat and the udder base of the heifers on $\mathrm{d} 115$ of the experiment was determined. The mean teat length of heifers on treatments 1,2 , and 3 was $2.3^{\mathrm{B}} \pm 0.28,2.8^{\mathrm{B}} \pm 0.40$ and $5.0^{\mathrm{A}} \pm 0.43$, respectively $(\mathrm{P}<0.01)$. This difference in teat and udder size disappeared during the next 6 months.

\section{Serum hormones}

Concentrations of insulin, IGF-1 and total thyroxin in the serum of heifers at d 30,150, 230 and 430 are presented in Table 5. Insulin concentration of heifers on treatment 2 was higher than that of control heifers only on $\mathrm{d} 430(\mathrm{P}<0.08)$. Maize gluten meal supplied to heifers on treatment 2 tended to increase serum IGF-1 concentration during d 150 and 180, as compared with control heifers (Table 4). The advantage in $\mathrm{WH}$ gained during this period was maintained until the end of the experiment, at the age of 19.5 months. A positive effect of dietary $\mathrm{CP}$ concentration on plasma concentration of IGF-1 in steers was reported (Elsasser et al., 1988). Serum lGF-1 concentration of heifers on treatment 3 was significantly higher than of control heifers on d 30 and 150 of the experiment. This result is in agreement with the positive effect of estradiol-17 $\beta$ on the IGF1 concentration in steers (Breier et al, 1987). An increase in plasma estradiol- 
$17 \beta$ concentration as a consequence of Synovex- $\mathrm{C}$ implantation in calves was found by Castree et al. (1988). No significant effect of the treatments on the total serum $\mathrm{T}_{4}$ concentration was noted (Table 4).

TABLE 4

Age, body weight and wither height (WH) of the heifers at puberty

\begin{tabular}{|c|c|c|c|c|c|}
\hline & \multicolumn{5}{|c|}{ Treatment' } \\
\hline & control & high $\mathrm{CP}$ & high $C P+S$ & SEM & $\mathrm{P}>\mathrm{F}$ \\
\hline Age, d & $249.6^{a}$ & $234.5^{\mathrm{ab}}$ & $211.7^{b}$ & 10.7 & 0.08 \\
\hline $\mathrm{BW}, \mathrm{kg}$ & 266.8 & 255.5 & 241.8 & 11.1 & $N S^{i}$ \\
\hline Withers height, $\mathrm{cm}$ & $109.6^{2}$ & $110.2^{a}$ & $105.1^{b}$ & 1.5 & 0.08 \\
\hline
\end{tabular}

a.b - means within a row without a common super script differ according to $P$ value given $c-P>0.1$

' see footnote in Table 2

TABLE 5

Blood insulin, IGF-1, and total thyroxin concentrations ( \pm SE) of the experimental heifers

\begin{tabular}{|c|c|c|c|c|c|}
\hline \multirow[b]{2}{*}{ Days on experiment } & \multicolumn{3}{|c|}{ Treatment' } & \multirow[t]{2}{*}{ SEM } & \multirow[t]{2}{*}{$\mathrm{P}>\mathrm{F}$} \\
\hline & 1 & 2 & 3 & & \\
\hline \multicolumn{6}{|l|}{ Insulin, $\mu \mathrm{U} / \mathrm{ml}$} \\
\hline 30 & 7.75 & 8.68 & 7.81 & 0.619 & $N S^{\mathrm{c}}$ \\
\hline 150 & 11.77 & 12.60 & 10.37 & 1.246 & NS \\
\hline 280 & 18.25 & 18.41 & 18.88 & 2.243 & NS \\
\hline 430 & $14.77^{\mathrm{b}}$ & $19.43^{i}$ & $16.49^{\mathrm{uh}}$ & 1.409 & 0.08 \\
\hline \multicolumn{6}{|l|}{ IGF-1, nmol/I } \\
\hline 30 & $15.56^{\mathrm{b}}$ & $15.78^{b}$ & $19.43^{*}$ & 0.866 & 0.03 \\
\hline 150 & $13.91^{\mathrm{b}}$ & $15.80^{\text {ab }}$ & $17.27^{\circ}$ & 0.892 & 0.05 \\
\hline 280 & 14.02 & 16.98 & 16.13 & 0.984 & NS \\
\hline 430 & 14.49 & 15.00 & 15.11 & 0.874 & NS \\
\hline \multicolumn{6}{|c|}{ Total thyroxin, $\mu \mathrm{g} / 100 \mathrm{ml}$} \\
\hline 30 & 5.92 & 5.82 & 5.27 & 0.368 & NS \\
\hline 150 & 5.96 & 7.06 & 6.59 & 0.368 & NS \\
\hline 280 & 6.07 & 6.42 & 6.24 & 0.298 & NS \\
\hline 430 & 5.19 & 5.80 & 5.78 & 0.321 & NS \\
\hline
\end{tabular}

a.b - means within a row without a common super script differ according to $P$ value given $c-P>0.1$

${ }^{1}$ sec footnote in Table 2 


\section{CONCLUSIONS}

The present data suggest that increasing dietary CP:energy ratio above NRC (1989) recommendations in diets for replacement heifers during the period from 3 to 9 months of age, enhanced BWG and skeletal growth rate without affecting the age of puberty attainment. Implantation of the growth promoter Synovex-C to 3-months-old heifers enhanced BWG but reduced skeletal growth rate. Likewise, it induced an earlier puberty attainment. The use of Synovex-C for replacement heifers might be reconsidered. It is assumed that enhanced skeletal growth could be better induced before pubertal attainment.

\section{ACKNOWLEDGEMENTS}

The authors gratefully acknowledge the technical assistance of Channa Lehrer and Moshe Nikbachat.

\section{REFERENCES}

Amos H.E., 1986. Influence of dietary protein degradability and energy concentration on growth of heifers and steers and intraruminal protein metabolism. J. Dairy Sci. 69, 2099-2110

Association of Official Analytical Chemists, 1970. Official Methods of Analysis of the Association of Official Agricultural Chemistry. 11 th Edition. AOAC, Washington, DC

Bagg J.G., Grieve D.G., Burton J.H., Sone J.B., 1985. Effect of protein on growth of Holstein heifer calves from 2 to 10 months. J. Dairy Sci. $68,2929-2939$

Barash H., Bar-Meir I., Bruckental I., 1994a. Effects of low-energy diet followed by a compensatory diet on growth, puberty, and milk production in dairy heifers. Livest. Prod. Sci. 39, 263-268

Barash H., Peri I., Gertler A., Bruckental I., 1994b. Effects of energy allowance and cimaterol feeding during the heifer rearing period on growth, puberty, and milk production. Anim. Prod. 59, $359-268$

Breier B.H., Gluckman P.D., Bass J.J., 1987. The somatotrophic axis in young steers: influence of nutritional status and ocstradiol-17 $\beta$ on hepatic high-and low-affinity somatorophic binding sites. J. Endocrinol. 116, 169-177

Casper D.P., Schingoehe D.J., Brouk M.J., Maiga H.A., 1994. Nonstructoral carbohydrate and undegradabic protein sources in diet : growth responses of dairy heifers. J. Dairy Sci. 77, 2595-2604

Castree J.W., Wettemann R.P., Lusby K.S., Cole E.R., Fox T.C., Kimbrough M.A., Kugler K.W., McDanial B.G., 1988. Plasma oestradiol after implanting calvcs with oestradiol benzoate. In: Animal Sciences Rescarch Report. Oklahoma Agr. Exp. Sta., Stillwater, OK, pp. 38-40

Deutscher D.W., Colburn G.D., Nielsen M., Davis R., 1991. Synovex-C implants affect growth and reproduction of heifers. In: Beef Cattle Report. University of Nebraska, Lincoln, NE, pp. 9-11 
Elsasser T.H., Rumsey T.S., Hammond A.C., Fayr R., 1988. Influence of parasitism on plasma concentrations of growth hormone, somatomedin- $\mathrm{C}$ and somatomedin binding proteins in calves. J. Endocrinol. 116, 191-200

Foldager J., Sejrsen K., 1991. Rearing intensity in dairy heifers and the effect on subsequent milk production Report No. 693. National Institute of Animal Sciences, Research Centre Foulum (Denmark)

Hanrahan J.P., Allen P., Sommer M., 1998. Food intake, growth and carcass composition of lambs treated with Cimaterol; effect of withdrawal period. In: J.F. Quirke, H. Schimd (Compilers). Control and Regulation of Animal Growth. Publication No. 36. Assoc. Anim. Prod. Wageningen (The Netherlands), pp. 149-161

Hardt P.E., Green L.W., Lunt D.K., 1995. Alterations in metacarpal characteristics in steers and heifers sequentially implanted with Synovex-C from 45 days of birth. J. Anim. Sci. 73, 55-62

Heinrichs A.J., 1993. Raising dairy replacement to meet the needs of the 21 st century. J. Dairy Sci. 76, 3179-3187

Heinrichs A.J., Hargrove G.L., 1987. Standards of weight and height for Holstein heifers. J. Dairy Sci. 70, 653-660

Heinrichs A.J., Rogers G.W., Cooper J.B., 1992. Predicting body weight and wither height in Holstein heifers using body measurements. J. Dairy Sci. 75, 3576-3581

Hoffman P.C., 1997. Optimum body size of Holstein replacement heifers. J. Anim. Sci. 75, 836-845

Kertz A.F., Prewitt L.R., Ballam J.M., 1987. Increased weight gain and effect on growth parameters of Holstein heifer calves from 3 to 12 months of age. J. Dairy Sci. 70, 1612-1622

Madar T., Dahlquist J., Stock R., Sindt M., Klopfenstin T., Lewis M., 1992. Feedlot cattle response to Synovex-C in suckling calves. In: Beef Reproduction. University of Nebraska, Lincoln. NE, pp. $27-29$

Markusfeld O., Ezra E., 1993. Body measurements, metritis, and postpartum performance of first lactation cows. J. Dairy Sci. 76, 3771-3777

National Research Council. Nutrient Requirements of Dairy Cattle, 1989. 6th Revised Edition. National Academy of Science. Washington, DC

Peri I., Gertler A., Bruckental I., Barash H., 1993. The effect of manipulation in energy allowance during the rearing period on hormone levels and milk production in heifers. J. Dairy Sci. 76, 742-751

Radcliff R.P., Vander M.J., Skidmore A.L., Chapin L.T., Radke B.R., Lloyd J.W., Stanisiewski P., Tucker H.A., 1997. Effects of diet and bovine somatotropin on heifer growth and mammary development. J. Dairy Sci. 80, 1996-2003

Roch J.F., Quirke J.F., 1986. The effect of steroid hormones and xenobiotes on growth of farm animals. In: P.J. Buttrey, D.B. Lindsay, N.B. Haynes (Editors). Control and Manipulation of Animal Growth. Butterworths, London, pp. 39-51

Rumsey T.S., Hammond A.C., 1990. Effect of intake level on metabolic response to estrogenic growth promoters in beef steers. J. Anim. Sci. 68, 4310-4318

Rusk C.P., Speer N.C., Scafer D.W., Brinks J.S., Odde K.G., LeFever D.G., 1992. Effects of Synovex$\mathrm{C}$ on growth, pelvic measurements and reproduction in Angus heifers. J. Anim. Sci. 70, Suppl. 1,126 (Abstr.)

Russell T., Turner B., Lawrence Riggs B., Spelsberg C., 1995. Skeletal effects of estrogen. In: Negro-Vilar, D. Bilke (Editors). Endocrine Reviews Monographs. 4. Hormonal Regulation of Bone Mineral Metabolism. A. The Endocrinology Society, Bethesda, MD, pp. 129

Ryan W.J., 1990. Compensatory growth in cattle and sheep. Nutr. Abstr. Rev. B. 60, 653-664

SAS Institute Inc, 1988. SAS/STAT ${ }^{\circ}$ User «s Guide Release 6.03 Edition, Cary, NC SAS Institute Inc., pp. 1028 
Sejrsen K., 1994. Relatioships between nutrition, puberty, and mammary gland development in cattle. Proc. Nutr. Soc. 53, 103-111

Tomilinson D.J., James R.E., McGilliard M. L., 1990. Effect of ration protein undegradability on intake, daily gain, feed efficiency, and body condition of Holstein heifers. J. Dairy Sci. 74, Suppl. 1, 169 (Abstr.)

Tomilinson D.J., James R.E., McGilliard M.L., 1991. Effect of nonstructural carbohydrate and rumen undegradable protein on intake, growth, feed efficiency, and body condition of Jersey heifers. J. Dairy Sci. 74, Suppl. 1, 214 (Abstr.)

Williams P.E.V., 1988. A short review and recent new data on effects of treating domestic livestock with beta-agonists. In: J.F. Quirke, H. Schimd (Compilers). Control and Regulation of Animal Growth. European Association for Animal Production, Publication No 36. Wageningen (The Netherlands), pp. 149-161

\section{STRESZCZENIE}

\section{Wpływ poziomu białka ogólnego w dawce i dodatku Synovexu-C na rozwój szkieletu u jalówek rasy mlecznej}

W doświadczeniu przeprowadzonym na 18 jałówkach izraelskich holsztynów, nie dojrzałych płciowo, badano wpływ dodatku białka i implantu Synovex-C na przyrostu masy ciała (BWG), rozwój szkieletu i wiek osiągniçcia dojrzałości płciowej. Jałówki podzielono na 3 grupy i żywiono następująco: l. dawka ułożona wg norm NRC (1989; kontrolna); 2. taka sama dawka, jak w grupic 1, lecz z dodatkicm 3,3\% mączki z glutenu kukurydzianego (MGM), podawana w ciaggu pierwszych 6-ciu miesięcy i z dodatkiem 2,5\% MGM, przez następne 3 miesiące; 3. dawka jak w grupie 2, lecz $z$ implantowanym preparatem Synovex-C.

Dodatek MGM do dawki zwiçkszał BWG w ciągu pierwszych 183 dni doświadczenia. Implantacja Synovexu-C zwiększała BWG tylko w ciągu pierwszych 92 dni doświadczenia. Przyrosty masy ciala jałówek grupy 3 od 93 do 281 dnia były niższe, podobnic jak i przy końcu doświadczenia; stwicrdzono przy tym tendencję do mnicjszej masy ciała w porównaniu z jałówkami grupy 2 . Dodatek MGM do dawki zwiększał tempo wzrostu mierzonego w klębic i biodrach w ciagu pierwszych 281 dni doświadczenia, a implantacja preparatu Synovex-C eliminowała ten wpływ tak, żc w końcu doświadczenia wysokość w kłębie i biodrach jałówek grupy 3 była mniejsza niż jałówek grupy l. Implantacja Synovex-C powodowała zwiększenie poziomu IGF-1 w surowicy krwi w pierwszych 150 dniach doświadczenia oraz obniżenje wieku i wysokości w kłębie przy osiągnięciu dojrzałości płciowej. 